\title{
War and Peace in Achaemenid Imperial Ideology
}

\author{
Christopher Tuplin
}

University of Liverpool

\begin{abstract}
Military activity played a determinative role in the history of the Achaemenid empire. This chapter considers some ideological dimensions of this fact. It does so through a separate examination of Persian and Greek representations of the role of war and warriors in the imperial setting. The place of war in the elite Persian psyche does remain rather elusive, but the Persian and Greek data-sets, radically different in content and character, are not far apart in their depiction of an ideological environment in which military values played a larger role than is sometimes acknowledged but were less fundamental than one might have expected. What is sometimes called the pax Achaemenica is certainly an artificial construct, but nothing compels us to replace it with the vision of a truly militarist society.
\end{abstract}

Key words: war, peace, heartland and periphery, religion, violence, demographic limitations.

In September 480 Xerxes, "the Great King, King of Kings, King of Lands containing many races, King on this great earth even far off, son of King Darius, an Achaemenid, a Persian, son of a Persian, an Aryan of Aryan lineage," was in Athens. The moment evokes the intricate link between religion and imperial violence. The acropolis sanctuaries were burned. But Athenian exiles were then told to conduct Athenian-style sacrifices on the site. Herodotus (8.54) speculated that Xerxes felt guilty and/or was influenced by an omen. We might see it differently. The burning avenged the sanctuary of Cybele in Sardis, burned nineteen years earlier (5.102, 6.101). Cybele was no Persian deity, but her sanctuary was part of the empire's religious infrastructure and its destruction demanded a response. Meanwhile, if Athens was to be part of that empire, its religious infrastructure must be absorbed, so the story could not end with a pile of ashes. The Persian king had to assert that his power, though due to his own gods, was acknowledged by those of his subjects. Yet religious multiculturalism is not evident in Xerxes' inscriptions. Ahuramazda is the only deity named, and one text $(\mathrm{XPh})$ reports suppression of daiva $\bar{a}$ worship in an unidentified land. There is an apparent mismatch between royal utterance and other evidence - something that will recur.

Xerxes' visit to Athens was the apogee of Persian imperial expansion. The westernmost advance of Persian arms occurred momentarily in early 479, but essentially the 
occupation of Attica brought the Persian empire to its widest extent. That empire was created, maintained and lost by military activity. This purpose of this essay is to consider the ideological dimension of this fact. ${ }^{1}$

The pattern of events from Cyrus to the 480s does not suggest reluctant imperialism. Herodotus certainly thought not, a perception culminating in his picture of Xerxes compelled to obey the "law" of conquest - a vivid suggestion that extension of empire was a structural necessity (7.12-18). Since empire is extended by warfare, one may wonder whether warfare was also a structural necessity. ${ }^{2}$ After 479 extension of empire ceased, but warfare did not (even if its focus was suppression of rebellion) and the same question can still arise. One difficulty in answering is that we have a very skewed data-set: our narrative of Achaemenid warfare is $90 \%$ Greek, and $80 \%$ of known military events before Alexander reached the Euphrates occurred west of that line. The dynamic of the conquest era is certainly more focused than that of the subsequent 150 years. A change of dynamic is potentially important ideologically and the difficulty of grasping the majority of Persian imperial history is inevitably worrying.

\section{Persian representations: texts}

Precisely because of Greek narrative dominance our first step in pursuit of war in Persian mentalité is to hear Persian voices. The loudest voice is that the king's, so I begin with royal inscriptions and monuments.

The earliest Achaemenid royal inscription is the Cyrus Cylinder. ${ }^{3}$ Intended to express Cyrus' role as beneficent restorer of divine order in Babylonia, it concedes that he came with a vast army, but insists that its weapons were fastened and it entered Babylon without fighting - a demilitarised picture of conquest, to which the Nabonidus Chronicle, Berossus and purely Greek sources give the lie. The main body of royal inscriptions are texts written in Old Persian, Akkadian, Elamite and (once) Aramaic and it falls into two groups - the Behistun text and all others. The military component of the latter is modest.

War can be a bad thing: threats to happiness are enemy armies, famine, and the Lie - human, natural and spiritual foes (DPd). It can also be a good thing: war suppresses disorder. ${ }^{4}$ Whether conquest of new territory counts as suppression of disorder is debatable: subordination of everything to the power and creativity of Ahuramazda raises the possibility that unconquered lands are (cosmically) disorderly spaces that demand

${ }^{1}$ I am indebted to Federicomaria Muccioli, Giusto Traina, Antonio Panaino and Andrea Piras for inviting me to the excellent, wide-ranging and hospitable conference from which this volume derives. A first version of this essay was presented as a lecture in Louvain-la-Neuve in March 2015, an opportunity for which I thank Jan Tavernier most warmly.

2 Aristotle's characterization of tyranny includes the proposition that war is promoted to keep people busy and in need of a leader (Pol.1313b19); earlier (1313a30) he treats Persia as a source from which tyrannical methods have been borrowed, but it is hard to say whether he consciously thought the promotion of war was one of them.

3 Schaudig 2001, 550-556; Kuhrt 2007, 70-74 (3.21).

${ }^{4} \mathrm{DB}, \mathrm{DNa}, \mathrm{DSe}$, XPf. On a cosmic scale it also ensures the defeat of Ahriman at the end of time, although this is only attested for the Achaemenid era in Theopompus (115F65). 
royal action. (Some such idea is arguably visible in Assyrian contexts. ${ }^{5}$ ) DPe affirms that the kāra (people/army) made subject peoples fear Darius and can protect the reader of the inscription from fear. There is acknowledgment here of a negative side to imperial conquest. (In DSe it is softened: what subjects fear is not the King but the King's law. ${ }^{6}$ ) There is also explicit stress on the conqueror's Persian identity: that recurs in statements on Darius' tomb that the "the Persian man's spear has gone far" and "the Persian man has repulsed the enemy far away from Persia" (DNa §4). ${ }^{7}$ The Persian land or "the kingdom" possesses good men and good horses (DPd, DSf, DSz) - and good chariots as well in two other texts (DSp, DSs), which is a step closer to an explicitly military statement. DPf calls Persepolis a fortress - perfectly accurate, but not a view we are apt to stress, so perhaps worthy of note - and DSe may refer to the fortification of Susa. But the elaborate description of Darius' building at Susa in DSf avoids any suggestion that it was even inter alia a military site.

In the second text on Darius' tomb (DNb), the King describes his virtues. He is a good "battle-maker" (hamaranakara), says he does not panic "when I see a rebel or do not see a rebel," and ends the main section with "I am fervent in counter-attack with both hands as well as both feet; as a horseman I am a good horseman, as a bowman I am a good bowman, both on foot and on horseback; as a spearman I am a good spearman, both on foot and on horseback." But the section's opening part concentrates on moral qualities - support of justice, defence of both strong and weak, hostility to the Lie, self-control, reward of co-operation and loyalty, punishment of those who cause harm, scepticism about one-sided denunciations. These qualities are, it is true, said to be visible in the king's behaviour "both at court and in battle" (a transition to the more military virtues mentioned above), but one might read this as a text that does not privilege the military environment. Or one might hold that because it ends with that environment it is actually privileging it. It is hard to decide. Meanwhile by speaking of lack of panic in the face of rebels (the term found passim in the Behistun inscription to describe Darius' rivals), the text pictures war as essentially a response to disorder. ${ }^{9}$

${ }^{5}$ Fighting enemies is assimilated to the conflict of Marduk and Tiamat: see e.g. ARAB 2.444-447, 561, 1001, Luckenbill 1924, 44, col. V, 67-45, 82. This attitude certainly coexists with an imperative to extend the empire's frontiers (an aspect of a more general imperative to outdo one's predecessors): SAA 3.11:3,17 (Assurbanipal); Sargon is "one who aggrandizes the border of Ashur" (Seux 1967, 234); Esarhaddon is empowered by the gods to attack, to plunder, to extend the border of Assyria (Borger 1956, 98: 34-35). The Elamite king was also commonly designated "the enlarger of the realm" (a phrase also applied to Neriglissar [C21 I.28]). In general see Tadmor 1999, with the further interesting idea that for Sennacherib the creation of Nineveh counted as a different species of extension of frontiers. I wonder if Darius might have had the same idea about Persepolis, for all that he also (of course) extended frontiers more conventionally.

${ }^{6}$ In the hieroglyphic Susa Statue text the king "inspires fear in the heart of humanity": Kuhrt 2007, 478 [11.2b].

${ }^{7}$ In otherwise somewhat comparable statements in DSab and DSz the phrasing is less explicitly military.

${ }^{8}$ The hieroglyphic Susa Statue text also celebrates the king's personal prowess: "master of his arm, when he rushes into battle, shooting precisely, his arrow never missing its goal, he whose strength is that of Montu." From earlier Egyptian contexts one may recall Amenhotep's ability to row, shoot and deal with horses and his having "no equal on the field of battle" (Lichtheim 1976, 41-42) or the one-man aristeia of Ramses in the Kadesh texts (Lichtheim 1976, 62 [bulletin], 64-70 [poem]).

${ }^{9}$ Again one may compare the Susa Statue text: "[Atum] has ordered him to conquer each of the two lands and the goddess Neith has given him the bow she holds, to throw back all his enemies, acting as she did on be- 
If we look in non-Behistun texts for allusions to specific contexts of warfare all we find are generic, if distinct, statements in $\mathrm{DNa}$, DSe and $\mathrm{XPh}$.

In DSe lands were in turmoil, men fought, and with Ahuramazda's help Darius caused them to stop, so everything was back in place, and fear of Darius' law prevented the strong from mistreating the weak. DNa is initially simpler: Ahuramazda saw the earth in turmoil, so made Darius king; Darius put everything back in place and people did what he told them. But we then slide via a reference to the accompanying depiction of the king's subjects into those statements about the Persian man and Persian spear. Perhaps there is a hint of that assimilation of restoration of order with conquest which I mentioned earlier and which might also be thought implicit in $\mathrm{DNb}$.

$\mathrm{XPh}$ is different again:

When I became king among the peoples listed above [the subject lands] there was one that was in turmoil. Then Ahuramazda gave me his help. By the grace of Ahuramazda I defeated that people and put it in its place. And among these peoples there was one where daiva $\bar{a}$ had been worshipped. Then by the favour of Ahuramazda I destroyed the sanctuary of the daiva and ordered 'The daiv $\bar{a}$ are not to be worshipped'. Where previously the daivā were worshipped, there I worshipped Ahuramazda.

So, where Darius confronts widespread turmoil, Xerxes confronts two specific threats, one involving turmoil, the other daivā-worship. In Darius' case we know there was widespread turmoil, and we are entitled to conclude that, when Xerxes produces a different version of start-of-reign disorder, he is referring to some real and distinct situation - though, as it is anonymized, we have no idea what he is talking about. ${ }^{10}$ But one point is worth making. Suppression of daiv $\bar{a}$-worship is followed by Xerxes worshipping Ahuramazda. But the daivā -worshippers are not made to worship Ahuramazda. Perhaps they have all been slaughtered, but more probably Xerxes is not concerned about their religious practice as long as it does not involve daiva . A precise, if obscure, religious issue seems to be at stake here, but it is only a limited challenge to religious multiculturalism.

Neither here nor in the other texts is there any evocation of actual military events. That is, by contrast, provided at Behistun. ${ }^{11}$ Many battles are mentioned, but proper narrative is replaced by stereotyped passages in which Darius or his generals "completely" defeat their opponents. Only the slightest more specific details emerge: defeated commanders flee with a few horsemen $(\S \S 20,32)$; survivors are driven into the Euphrates $(§ 19)$; Persians cross the Tigris on horses, camels and improvised boats (§18); on Skunkha is attacked across a sea $(\$ 74),{ }^{12}$ and in the battle Darius captures some of the enemy while others are brought in chains, hinting at a narrative in which fugitives were chased down afterwards. Engagements at a fortress are not a different sort of event from

half of her son Re, on the first occasion [i.e. creation], so that he may be effective in repelling those who rebel against him, to reduce those who rebel against him in the two lands" (Kuhrt 2007, 478 [11.2b]). But there is also then a generic reference to "crushing the nine bows," a matter of external conquest.

10 Jacobs 2014 has rightly insisted that some real event(s) lie behind these statements. Henkelman (2008, 9-10) rightly notes an affinity with IRS 62, wherein the Elamite ruler Tepti-Huban-Insušnak notes he has destroyed the land of the evil-doers (balahuteppe) and the enemies (lallarippe) and has built a temple for the goddess Pinigir.

11 The stark contrast between DB and later royal inscriptions is well-known: cf. Sancisi-Weerdenburg 1999 and Jacobs 2014, the latter characterizing the shift as one from legitimation by personal ability (Befähigung) to legitimation through divine favour.

12 Rollinger (2016a, 150) proposes to see this as a matter of ideologically inspired virtual geography. 
those at villages or other places; but when Darius "seized Babylon and killed NidintuBel” (\$20) that may be a distinct category. (How Darius did it is unstated. Nidintu-Bel had already lost two entire armies, so perhaps it was not hard.) A striking feature of the Aramaic and Akkadian versions is the inclusion of figures for dead and captured enemies, ranging from a few hundreds to 55,243 dead and 6972 captured in Margiana (DB §38), 34,425 dead and over 18,000 captured at Kunduru (\$31), and 35,404 dead at Rakha (§41). In two cases where no figures are provided ( $\S 18-19)$ we read that the entire enemy army was killed and no prisoners were taken, and the same may be implied at Izala (§29), where there is only a figure for the dead. Battle-descriptions are the same whether casualties were high or low, so we cannot tell why slaughter is sometimes so extravagant; but the figures presuppose the counting not only of prisoners (who would be put to economic use) but also of corpses, something otherwise unattested. But all told, Behistun has little for the historian of Achaemenid warfare or military institutions. And it is arguable what it says about the military component of royal ideology: does it evoke the reliable and bloody efficiency of the forces of good order; or is this over-interpretation of a relentless use of descriptive stereotype that is really a sign of disinterest in the human mechanics of divinely promoted success?

\section{Persian representations: iconography}

Still, Behistun openly acknowledges Persian military violence. Things look different in monumental royal iconography - the visual decoration of the Behistun monument, the walls of Persepolis and the tomb of Darius at Naqsh-i Rustam. (Little remains from Susa.) The subject peoples who hold the king aloft on the tomb facades are said to be the result of Persian military conquest $(\mathrm{DNa} \S 4)$ but that is not the guise, and the only acts of human violence are (a) Darius treading on Gaumata at Behistun and (b) recurrent Persepolitan images of a heroic figure killing an animal-monster (Root 1979, 303-308). The former is part of an entirely symbolic expression of Darius' triumph whose mood is distant from the record of battles in the accompanying text. ${ }^{13}$ The latter doubtless symbolizes the ability to check the power of disorder. (The one recurrent image of nonhuman violence, the lion-bull symplegma, is a different mythical take on this idea. ${ }^{14}$ ) It is possible that viewers of the hero-v-monster icon saw metaphorical expression of military power (the format recurs in human combat in non-royal monuments), but the preference for metaphorical expression is obviously significant.

Markers of real warfare do appear. The King carries a bow at Naqsh-i Rustam and Behistun. Both there and on the Apadana he has weapon-carrying attendants. His chariot appears on the Apadana. Some Apadana gift-bearers bring weapons as gifts. All Tomb-

${ }^{13}$ Rollinger 2016b stresses that Darius is trampling on a still living Gaumata while engaging in legitimating interaction with his god - an Old Babylonian trope largely absent from the surviving record until Darius revived it. In a sense this is a more violent image than what had become normal in the interim (the victor trampling dead enemy bodies), but that is fairly plainly not the icon's primary intent.

14 The hero stabs the monster, so certainly kills him; the lion pounces on the bull, but is perhaps not quite so clearly shown killing him - the image is more about mastery than annihilation. (For some, of course, the primary reference of the image is to gods and/or astronomical phenomena.) 
facade subjects (except the Babylonian) carry weapons - something that is, however, not true of similar figures at Persepolis. But none of this alters the basic fact that royal monumental iconography avoids warfare as a subject and concentrates instead on showing the king in communion with his god, held aloft by contented subjects and enthroned at the centre of a world defined by dignified gift-bringing subjects and courtiers in robes or riding dress. It is an imagery designed to suggest order, even peace, and to suppress the violent means by which such things may be achieved and maintained. And the effect seems particularly strong for anyone able to contrast it with the iconography of Assyrian palaces, which rejoices in extensive, detailed and at times distastefully cruel representations of professionally competent military action. The gulf between that and the Apadana composition, the fullest symbolic encapsulation of the Achaemenid world, is enormous. The view that Persepolitan royal monuments advertise the pax Achaemenica is easy to understand.

Nor do I intend to dissent. But there is a further feature that requires attention. For much the most common figure on Persepolitan walls is not the king, the courtier or the subject. It is actually the soldier. Spearmen and spearmen-archers were to be seen everywhere: there are some in the Apadana composition, but they also occupy spaces more or less remote from the headline icons. (They are also the only preserved aspect of Susa's iconography and were found in the so-called Perserbau in Babylon and at lower level prestige sites in Fars.).

Why are there so many? Surely not to indicate fear for the security of the king: it would be embarrassing to suggest the royal person was under threat. The Apadana and the other icons are symbolic representations, the soldiers are similarly symbolic, and what they symbolize is military power - inactive, but potentially available. The "spear of the Persian man has gone far" of DNa is salient here. It is true that military force, though omnipresent, is often relatively peripheral compared with subjects and the court. But some courtier-figures in rider-costume carry bow-and-arrow cases, one group of soldiers is closer to the king than are any courtiers, and on the doorway of the 100 Column Hall the ranks of figures beneath the king are not subjects but armed men. Although the prevailing iconographic idea may be the empire-at-ease and the king-as-gift-recipient not king-as-war-leader, it is an armed empire - or an empire with a copiously armed ruling nation, for all the armed men of Persepolis are Iranians. ${ }^{15}$ In the hero-fights-monster icon we see, in highly symbolic form, the violence that is needed to maintain order. In the less mythic symbolism of the other iconography violence is shunned. But, if we are being confronted with an iconography of peace, we are also reminded of an old cliché: "if you wish peace, prepare for war."16

Some acknowledgment of war also appears in a quite different form of royal iconography. The design of darics and sigloi changes over time but always features an armed

15 It is worth recalling Calmeyer's alignment of the Apadana images with Phylarchus' description of the enthroned Alexander (1983, 144): no one would think of Alexander's environment as unmilitarized, and we should not think of Great King's that way either.

${ }_{16}$ An early visual encapsulation of the interconnection of war and peace is provided by the so-called Standard of Ur. One may also recall Res Gestae 13 (cum per totum imperium populi Romani terra marique esset parta victoriis pax) - from another imperial environment whose ideological celebration of peace has perhaps informed some reactions to the Achaemenid case. 
royal figure. The earliest design evokes Behistun and is static, but in Type II the king shoots his bow and in the dominant Type III/IV design he runs holding bow and spear or dagger. No opponent is shown, but these images will have been read as essentially military. Confirmation comes from a late period coinage in which the Type II archer appears on one side while the other shows a charging sword-wielding cavalryman, again without specified opponent but inescapably in military mode. ${ }^{17}$

So far as the king's voice goes, then, we may say that:

- War is present more than is sometimes realized, but (outside the Behistun text) in a subdued way.

- There is a contrast between verbal and visual voices: Behistun reports battles, the tomb-inscriptions present the King as warrior and celebrate the Persian spear, Xerxes' daiva $\bar{a}$ text evokes violent operations; images never get that close to specific military violence - at most we see results (Behistun, tomb-facade subjects) or potential (spearmen; coin images).

- The isolation of Behistun text (full of military events) and icon (the only time a king engages in violence, albeit not military violence) is clear. Both were disseminated widely, and conveying their message mattered. But it was a one-off. That is evidence of very deliberate choices being made in this domain.

- The post-Behistun royal voice is consistent in downplaying the actuality of warfare while acknowledging its existence within the pax Achaemenica.

Are there other non-royal Persian voices we can hear? Not easily. The Persian elite does not speak to us verbally in any salient fashion. The satraps Arshama and Akhvamazda (in archives from Egypt and Bactria) do engage with military infrastructure but not to express an evaluative or ideological view. We can observe in the Bactrian archive that apparent soldiers get used on non-military tasks as a matter of course (ADAB A2, A4); and there is a broader sense in Babylonian documentation of a certain fluidity between "man" ( $s a b)$ as soldier and "man" as worker - the men in both cases being notionally nothing more than performers of service-obligations to the state. There is a similar fluidity in the OP word kāra as between "people" and "army." But it is debatable what ideological inference can be drawn from these facts. Some might say that the ambiguity of $k \bar{a} r a$ is an interesting accentuation of the military identity of the Persian people. Others might say the exact opposite - that the Persian people are only casually military. ${ }^{18}$

But one member of the elite does, perhaps, speak to us visually. The satrap Arshama had a very fine seal, several impressions of which were found with the letters now in the Bodleian. ${ }^{19}$ This shows a Persian soldier killing a Central Asia nomad. In other words, it provides what is missing in the royal repertoire: an image of actual human combat. True, the seal was inherited from an ancestor who was the son of Darius I (Garrison [forthcoming]), so we are in the inner confines of the royal family. But whether we see the satrap Arshama as quasi-royal or not matters less than the fact that he used an image that directly encoded Persian military success.

17 See Tuplin 2014a.

18 It is similarly as difficult to say how far the terminology of bow-land or bow taxes in Achaemenid Babylonia evoked warfare ideologically as it is to say how far the silver income they produced was expended in specifically military fashions.

19 Boardman 2000, 164-165, fig. 5.21. 
It is not easy to find a precise analogy - something unambiguously linking a highranking Persian with direct celebration of warfare. For example, the putative seal of a late Achaemenid general Vishtaspa, a man also known from classical sources, bears an image of hunting, not warfare. ${ }^{20}$ It is true that the animal hunted is a lion (a potentially royal quarry) and the seal is exceptional in the wider repertoire of seal-stone lion-hunts in showing two lions and two hunters of differing sorts (equestrian and foot). But it is at best an entirely metaphorical allusion to human conflict - like the hero-and-monster images at Persepolis.

But Arshama's seal invites us to look for other images of human combat, and this turns out to be productive. For it is a prime exhibit in a whole class of Achaemenid era seals showing human military combat. ${ }^{21}$ Salient facts include:

- 63 items show Persian victory in human combat.

- Provenances include Persepolis, Nippur, and Dascylium but two thirds are unprovenanced. They vary in type of seal (cylinder/stamp/finger-ring) and style. The set is homogeneous only in the type of scene depicted.

- Mostly they show combat between two figures; sometimes there are more combatants, sometimes other additions. The potential for complexity can be seen at its richest in these items.

- Equestrian combat is simple: a horseman assaults a infantry figure with a spear or chases away enemy horsemen. Infantry combat contains some repeated features: the enemy-grab trope, which calques hero-monster confrontation; the two-handed-longspear; the inactive Greek opponent with crossed spears; prisoners. But there is also variety and uniqueness.

These items are almost the only scenes of human military combat in the entire database of seal-stones made in Greece or the Near East during the Achaemenid era. Our small corpus completely dominates the relevant field. In that context its wide stylistic range increases its significance. It is not an accident that Persians defeat Greek horsemen on (Greek) gemstones and Central Asian infantry on (Near Eastern) cylinders, but this fact underlines the affirmation of Persian power shared by the relevant user-groups. Different people buy into an expression of Persian dominance through military combat whose ultimate origin must be Persian; and it is an type of expression of dominance not used on seal-stones by any other group in the same geo-historical space. We find here what is absent in royal monuments and texts of the heartland - and we find it in the heartland, as some seals are Persepolitan.

The adversaries are normally Central Asian, Egyptian or Greek. Egyptians are rarest. Greek infantry adversaries are the norm in equestrian scenes (four exceptions all involve equestrian enemies) and only slightly less common than Central Asiatics in infantry scenes. The dominant adversaries are thus from the empire's margins. The principle recurs in the few depictions of Persian military victory in other media: one may mention the Tatarlı battle-scene (Central Asians), the Çan sarcophagus (Greeks or Mysians) and one of the Clazomenae sarcophagi (Thracians). ${ }^{22}$ War is something happening at the empire's edge.

\footnotetext{
${ }^{20}$ ADAB C2 (plate on p.187); Hyland 2013.

21 For full presentation of material see Tuplin (forthcoming [a]).

22 Sevinç et al. 2001; Summerer 2007, 2009, 2010; Cook 1982, G.11 (Izmir 3493).
} 
Persian infantrymen can be royal or non-royal; Persian horsemen are always nonroyal. The non-royal ones often wear a distinctive cuirass, and infantry and cavalry ones distinct headgear: there is documentary exactitude here. But the fact that royal and some non-royal figures wear the Persian robe (which is not really a battlefield garment) reminds us that there is symbolism too. But what is most striking is the predominance of non-royal figures. This iconography characterizes war as something done by "ordinary" Persian soldiers.

These two features - ordinary soldiers, fighting at the frontiers - recall Darius' vision of the spear of the Persian man, especially as spears well outnumber bows in the seal-stone iconography. In other words the seal-stone repertoire (and analogies in other non-royal monuments) provide, not a contrast, but a complement to the royal repertoire.

Three further observations. (1) There is an analogy for this. Greek evidence indicates that hunting was an important activity for kings and the elite. There is no hint in royal monuments. But hunting is a major subject on seal-stones and in larger-scale items from the imperial periphery. Mutatis mutandis one may also remember the mismatch between royal texts and historical record on religious multiculturalism. (2) Heartland monumental images travelled - and on seal-stones. So sometimes those images and images of warfare did end up co-existing in a fuller mirror of ideological concerns. (3) Seal-stone combat occurs at the periphery. Ideologically that is where war should be. Suppression of actual warfare in heartland monuments is part of an ideological package. Those who entered the inner parts of Assyrian palaces were subjected to extensive and vivid images of war because Assyrians were happy to recreate the periphery (which for them too was the actual locus of war) in the penetralia of the empire in order to frighten visitors and encourage their own people. ${ }^{23}$ The Persians made a radically different choice.

So radically different, indeed, that one may hesitate to see it as purely rhetorical. For we still have a problem. Even if a corpus of seal-stones can justify crediting Achaemenid Persians with a more robust valuation of war, can it encourage us to think they were as wrapped up in war-making as we think the Assyrians were? ${ }^{24}$ Is it a purely rhetorical choice that Assyrians (perhaps) over-stated and Persians under-stated a broadly similar degree of bellicosity and militarism? Or is a decision to keep warfare at the imperial margins ideologically a clue that Persians also wanted it there psychologically - wanted to feel that, although warfare might be a necessity, it need not be an obsession? The Assyrians present an extreme case by the standards of all Ancient Near Eastern environments, but this observation does not eliminate the question - and even underlines how far most of the Persian material is in the other direction. ${ }^{25}$ We still have not established

${ }^{23}$ That both things are involved is stressed by e.g. Fuchs 2009 and Liverani 2014.

${ }^{24}$ Van der Spek $(1996,130)$ remarks that Assyrians displayed "love of war for its own sake" (his italics). The Assyrians certainly stand out both for the length and detail of their military narratives and pictures and for the unconcealed brutality of some of the material.

${ }^{25}$ There was a preference for seeing the Neo-Babylonian king as religious leader and teacher of wisdom rather than conqueror, administrator or dispenser of social justice (Beaulieu 2007, 142), and it was the king's pious behaviour that led the gods to favour him, so royal inscriptions stress building or restoration and maintenance of ritual continuity and generally neglect military behaviour (Da Riva 2008, 28), although there are generic allusions to warfare or to the building of defensive walls. Specific and geographically located military events are occasionally mentioned, but not narrated with much detail or colour. All such cases are exceptional in one way or another, but the situation does differ from that in Persian royal inscriptions in that the cases 
how deeply a military function was embedded in the basic identity of the Iranian elite or indeed determined whether that is something we can hope to establish.

Can we get anywhere by inspecting the perceptions embedded in Greek sources? ${ }^{26}$ Did Greeks think king, court or empire were militarized? What did they see as the "tone" of Achaemenid military activity?

\section{Greek representations: a military empire?}

Greek observers credited the empire with military tendencies: thus Xenophon in Cyropaedia, Plato in Laws (694a-696a, 697c-698a) and, of course, Herodotus: his Achaemenid kings obey an imperative to extend the empire to the ends of the sunlit earth - a ideological proposition we should not too hastily dismiss as a Hellenic literary and philosophical projection. ${ }^{27}$ Persians appeared in Greeks lists of warlike barbarians: Socrates reportedly said that Persians were the bravest and most free barbarians, Heraclides Ponticus the noblest and most courageous. ${ }^{28}$ Not all Iranians were the same, of course; some Alexander historians thought Bactrians more scary (Curtius 4.6.3, 4.13.5) - and Alexander certainly faced troublesome resistance there and in Sogdiana. Interestingly, lists of warlike people could also include Spartans: as warriors Persians were in good company. That said, whereas over-concentration on military virtue was an explanation advanced for imperial decline in Sparta and Thebes, ${ }^{29}$ that idea never occurred to Greek viewers of Persia, who were more inclined to detect the enervating effects of wealth: ${ }^{30}$ Heraclides' suggestion

are more numerous and are not all found at the beginning of the corpus. Mutatis mutandis the same goes for specific allusions to military action in Elamite royal inscriptions. Of course, neither Babylonians, Elamites nor (even) Assyrians produce seal-images of warfare in the way the Achaemenid environment did.

${ }^{26}$ For a compelling reminder that Greek texts, or at any rate Herodotus, can encode Persian ideology, while developing their own (often contrarian) literary and interpretative strategies, see Harrison 2015.

${ }^{27}$ The sun trope in Hdt.7.8 $\gamma$ has an analogue in the Assyrian assimilation of king and sun (Seux 1967, 283-285; Parpola 1983, 130; Tadmor 1994, 158,1-4), as does the imperative to extend imperial frontiers (see above n. 5). Meanwhile in the Egyptian tradition Darius is "master of all that the sun's disc describes," a notion with New Kingdom antecedents: cf. Thutmose's Karnak Poetical Stele (Lichtheim 1976, 36) and the Sphinx Stela of Amenhotep (Lichtheim 1976, 41). Concomitantly Egyptian discourse affirms that Darius has been given "all countries of the plain and all countries of the mountains united under your sandals" - again with New Kingdom parallels: "the princes of all lands are gathered in your grasp"; "you trod all foreign lands with joyful heart" (Thutmose: Lichtheim 1976, 36), "all foreign countries were bound under his soles" (Amenhotep: Lichtheim 1976, 42). As for Persian discourse, I remain impressed by Clarisse Herrenschmidt's argument (1976) for the implicit assimilation of empire and entire earth (bümi). Note, incidentally, that in terms of her analysis the shift from "king of lands containing all kinds of men" to "king of lands containing many kinds of men" is not a sign that an aspiration to universal rule has been abandoned (or never existed), but a pedantic recognition that the lands (the specific entities actually listed as ruled by the king on any occasion) constitute a limited group, though necessarily a closed one. Similarly speculation about Persian plans for mainland Greece (Wiesehöfer 2004) belongs at best in the mundane sphere of "lands," not the ideological one of bümi-empire. For a powerful reassertion of the difference between virtual and real geography in the matter of universal conquest (primarily in a Neo-Babylonian context), see Rollinger 2016a.

28 Ar. Pol. 1324b, Plat. Leg. 637de; Ael. VH 10.14; Heraclid. fr. 55 Wehrli = Athen. 512A-D.

29 Ar. Pol. 1271b, Ephor. 70F119.

${ }^{30}$ Leading inter alia to lack of exercise and physical feebleness (Xen., Cyr. 8.8.8, 12); cf. Isoc. 4.151, Xen., Hell. 3.4.19; An. 3.1.23. Yet in a different discursive setting Persians are physically large (Just. 11.13; Curt. 4.13.5, 7.4.6); and Herodotus knew of individual large Persians (7.117, 9.25, 83, 96). 
that Persian respect for pleasure and luxury co-existed constructively with courage and nobility was perhaps deliberately paradoxical. Still, Clearchus (fr. 49 Wehrli), if taken at face value, might suggest that the Persians were conscious of the danger, ${ }^{31}$ and - less contentiously - the final chapter of Herodotus' Histories certainly allows that Persians were once hard men from a hard land, and perhaps implies this explained their success.

An earlier Herodotean chapter (1.136) affirms that the first Persian measure of manliness is being good at fighting, the second fathering many children, strength being held to consist in numbers. In a strange echo Diodorus (19.21.4) would write that the most warlike Persians came from the most populous part of Persia, which also had the best climate and productivity - a reversal of the trope in Herodotus' final chapter. This world of military and sexual manliness was one in which the worst insult is to be called more cowardly than a woman (9.107) - but it is also a world in which elite Persian women think wool-working disgraceful (Curtius 3.2.19), there are stories of martial Persian women, ${ }^{32}$ and real Persians had no problem with actual (non-Persian) women on the battlefield (Artemisia in Xerxes' fleet, Mania the subordinate of Pharnabazus ${ }^{33}$ ). It is to a woman that Xerxes offers an army which "nobody but she could command," something Herodotus calls a very Persian gift (9.109). This is perhaps actually just about ownership of landed property that might support military forces (Sancisi-Weerdenburg 1988). Even so, high-status Persian women have possibilities unknown to most Greek ones. That perhaps fuelled Greek notions of Persian feminization. But empowered women can co-exist with militarized men. The case of Sparta comes to mind once again.

One text affirming a royal concern for war is Xenophon Oeconomicus 4. More precisely it makes the provocative claim that the king is as concerned about agriculture as about warfare. The two are connected, for high productivity enables tribute to be paid and the military occupation of imperial provinces to be properly maintained. Good performance is checked by the king or his agents, and, in a parallel passage in Cyropaedia, the agents come annually with an army (8.6.16). The precise historical reliability of such data is debatable, ${ }^{34}$ but they do assign the military a structural significance - albeit in a fiscal rather than a militarist framework.

Something different is found in a more famous passage, Mardonius' remarks in Herodotus VII on Greek fighting methods (7.9ß). Greeks, he says, are irrational and pig-headed; so (a) they fight wars that they should not fight (because they could settle disputes by diplomacy) and (b) they choose to fight battles on flat and easy land, which

31 "Because of truphe the Medes made many surrounding people (periktiones) eunuchs. The Persians took over mélophoria from the Medes not only as punishment for what they suffered but also a reminder of the degree of anandria (cowardice? degradation?) reached by the truphe of the doruphorountes. For, it seems, their inopportune (parakairos) and vain truphe peri ton bion can make those armed with spears into agurtai (mendicant priests)." Wehrli suggests the last comment hides some analogy between thyrsoi and spears; the Loeb note alludes to emasculated Cybele priests. Are we to read this as a (serious) claim that Persians sought to resist tendency to degradation and used mélophoria as a permanent warning to themselves not to become Median? Well, perhaps not. There is clearly much to be said for the view that Athenaeus misunderstood or misrepresented Clearchus: Gorman/Gorman 2010; Charles/Anagnostou-Laoutides 2016.

32 Rhodogune: Paradoxographi 215-216 Westermann; Philostr. Imag. 2.5; Polyaen. 8.27; Dio Chrys. 64.2. Rhoxane: Ctes. 688F15(54).

33 Hdt. 7.99, 8.68-69, 87-88, 93, 101-103, 107; Xen., Hell. 3.1.13.

34 See Tuplin (forthcoming [b]) on the context and character of the Oeconomicus passage. 
results in huge losses for victors and annihilation for losers; what they ought to do is choose ground where both sides are "hardest to defeat." As a result they failed to resist Mardonius when he marched to Macedonia in 492. Herodotus is perhaps trying to illuminate Persian views about warfare by capturing a contrast between people for whom war is about dispute resolution and those (like Mardonius) for whom it is about conquest of new territory. ${ }^{35}$

When the situation arose, was fighting necessarily the preferred option? The invitation to acknowledge Persian suzerainty by giving earth and water (characteristic of the later conquest era) encodes a claim to complete control of the subject's means of subsistence, but it also gets it without fighting: extension of frontiers was more important than having an excuse to fight. ${ }^{36}$ The historical record contains a number of cases in which Persians seek to forestall future fighting or terminate existing fighting by negotiation, and very few when they refuse to talk. And the imperial system is one that can accept containment or symbiosis rather than annihilation, even at the cost of local instability: this is seen in the Egyptian Delta, the Zagros and upland parts of central/west Anatolia. ${ }^{37}$ Some of these afforded the possibility of intermittent low-level military activity but there is no suggestion that this was to ensure that Iranians could practise military skills or fulfil a need to earn military glory.

Nor, when war was in question, was there settled objection to indirect means of waging it: surprise attacks, stratagems, bribery and delaying tactics were acceptable campaign and battlefield strategy. There are, it is true, occasional counter-indications, most famously the Anatolian satraps' response to Memnon's proposal to resist Alexander by a scorched earth policy combined with naval counter-attack. In Diodorus the strategy was denounced as inconsistent with Persian high-mindedness - a straightforward code-of-honour claim. ${ }^{38}$ But in Arrian Arsites' refusal to tolerate harm to his subjects' property was endorsed by others because they were jealous of Memnon's status in the King's eyes. Both aspects of Memnon's proposal have analogies before and after $334 \mathrm{BC}$, of course, so were tolerable on other occasions. ${ }^{39}$ Perhaps there was a theoretical ideological attachment to straightforward forms of warfare. But largely Persians were pragmatists.

35 Harrison $(2015,32)$ sees it as representing the puzzlement of someone from a multilingual empire that monoligual Greeks could not settle disputes without ruinous fighting. For another reading again, stressing an ironic, even satirical, tone, see Konijnendijk 2016.

${ }^{36}$ On earth and water, see variously Orlin 1976; Kuhrt 1988; Nenci 2001; Kramer 2004; Tuplin 2010, 259-262; Rung 2015.

37 Delta princes: Hdt. 3.15; Thuc. 1.110, 112; Philoch. 328 F119. Mysians, Pisidians: Xen., Hell. 3.1.13; An. 1.1.11, 1.6.7, 1.9.14, 2.5.13, 3.2.23; Mem. 3.5.26; Diod. 11.61.4; Arr. 1.24.6, 1.27-28. Cossaeans, Uxians (Zagros): Arr. 3.17; Strabo 15.3.4; Nearch. ap. Strabo 11.13.6; Diod. 17.91, 19.19. Cadusia: Xen., Hell. 2.1.13; Nic. Dam. 90 F66 (11-16); Diod. 15.8,10, 17.6; Pomp. Trog., Prol. 10; Plut., Artax. 24 ; Just. 10.3 .

38 Compare Darius' supposed decision not to resist Alexander's landing, because there was more honour in repelling than preventing access: Just. 11.6.8. Spithridates' abandonment of Agesilaus in a quarrel about booty-allocation illustrates a different effect of a Persian's sense of honour in a military context (Xen., Hell. 4.1.26-28), as do e.g. Artaxerxes II's insistence that it was he who killed his brother (Plut., Artax. 16, 25), the dissidence of Megabyzus (Ctes. 688 F14[40]), the potential dissidence of Pharnabazus (Xen., Hell. 4.1.29-40) and perhaps some of what happened during the now rather mystifying era of the so-called Satraps' Revolt.

${ }^{3}$ Strabo 13.1.22; Xen., An. 1.6.1, 2.5.19, 3.5.3; Curt. 3.4.3, 14, 4.9.7, 12-14, 10.11-14; Arr. 3.19, 28. 


\section{Greek representations: a warrior elite?}

When Herodotus affirms that the two marks of manliness are quality as a fighter and success in procreation, he notes that the latter earned royal rewards. So did the former: people took notes at Salamis to ensure that those who fought well would be listed as royal benefactors. ${ }^{40}$ But, although Greeks were well aware of royal gift-giving, reports of it rarely arise in specifically military contexts. Camisares, father of Datames, was given a low-rank provincial governorship because he was brave, militarily energetic and repeatedly loyal to the king. His son succeeded on his father's death on a similar basis: he was the palace-guards under Artaxerxes II and served well during the disastrous Cadusian campaign (Nepos, Datames 1). But we lack systematic information about military careers and cannot judge how much meritocracy there was. The jealousy that prompted Datames to abandon an invasion of Egypt and seek autonomy in central Anatolia suggests some thought him too much of an outsider for such a high role (5). Meanwhile, fulfilling the aspiration to be happy when alive and blessed $(r t \bar{a} v \bar{a})$ when dead, as the language of royal inscriptions has it (XPh $\S 7$ ), depends on loyalty to the king - just one of the two grounds for Datames' promotion. And a specifically military reputation is rarely mentioned in Greek characterizations of members of the elite. Orontes was "reportedly among the best of Persians in military matters" (Xenophon, Anabasis 1.6.1), Mardonius was "among the first of Persians for physically bravery and ability to offer counsel" (Nepos, Pausanias 1.2), Spithrobates "excelled in manliness" (Diodorus 17.19.2) and Artaxerxes I "enhanced his physical stature and beauty with bravery in war: for no Persian excelled him in feats of arms" (Nepos, de regibus 1.3). But such passages are rare. Greeks do not see top Persians as top primarily by virtue of feats of arms.

Such people did, of course, fight personally. The deaths of satraps and others fighting Alexander prove this. ${ }^{41}$ So do such things as Xenophon's vignette of Pharnabazus riding into the sea at Abydus to fight off Athenian attempts to drag away disabled Spartan ships (Hellenica 1.1.6). There is a high proportion of known members of the royal family or relatives of Darius' six companions in the top level commanders of the Xerxes army (32 out of 48). In the rest of Achaemenid history one also finds plenty of high-rank commanders who fall into these categories. But there are also plenty who do not - or at not known to: that is true of most of the known high-rank participants at Granicus, Issus and Gaugamela (23 out of c. 30), and at least 30 other individuals (including famous names: Tiribazus, Mazaeus, Tithraustes). Herodotus' Army List is an exceptionally detailed document: material from elsewhere may under-represent the phenomenon. But it may also be dealing with an exceptional situation - a grandly royal enterprise in which the royal family figured unusually richly. It is impossible to know. High-level military commanders were certainly essentially from the satrapal or quasi-satrapal elite; and nothing compels us to think they often come from a very wide pool. Lower down the hierarchy Greek sources are prosopographically almost mute. The equivalents of the Iranian contingent commanders in the Elephantine garrison are unseen in Greek texts; ${ }^{42}$ and we have no

\footnotetext{
40 Hdt. 8.85, 88, 90 .

41 E.g. Arr. 1.16.3, 2.11.8; Diod. 17.21.2, 34.5; Curt. 3.11.10.

42 TADAE B2.2-4, 6-8, 11; B3.3-4; B7.2; D2.12.
} 
way of knowing whether such people might ever have progressed to more distinguished positions of command. In the world of Cyropaedia a former common-or-garden Persian called Pheraulas rises to the highest rank; ${ }^{43}$ how common that was in the real world, especially after the first generation is impossible to tell. Nor can we tell how far the social obligation to fight created a specifically military aristocratic ethos.

The grandest individual was, of course, the King. Various texts indicate that the King was supposed to be physically impressive. ${ }^{44}$ Few make this as an explicitly military proposition. (In Plutarch, Alexander 23 Darius' appearance and stature are a counterpart to his wife's beauty. On the other hand Alexander 33 notes the physically impressive quality of the king and his entourage at Gaugamela.) Even Herodotus' statement that in stature and beauty none deserved victory more than Xerxes (7.187) may only mean he excelled everyone else, not that it deserved to earn him military victory. Several stories assume that even in his palace the King has a bow and/or spear to hand: that matches the iconography of king and weapon-carrier, but is only very vaguely expressive of a militarized king. ${ }^{45}$ One source tradition presented Cyrus' tomb as a warrior burial (containing shield, bows and a sword), but the more authoritative one perceived only the swords (akinakai) that were part of personal adornment. ${ }^{46}$ Cyrus also plays a role in the rituals of royal accession: Plutarch reports that the king-to-be enters the temple of a warlike deity, puts on clothes worn by Cyrus before he was king, and eats figs, terebinth and sour milk. This rite of passage plays on the plain origins of the state, but the simple foods recall what Strabo says about the training of Persian soldiers, and the warlike deity is of a piece. ${ }^{47}$ That deity has been variously identified as Anahita and the fravashi (heroized spirit) of Cyrus, the temple as the Pasargadae Zendan-i Sulaiman - but scepticism has been expressed about the whole report. If it stands, it casts a modest but antiquarian veneer of militarism over the kingly office.

Every Achaemenid king, apart from Artaxerxes IV (so far as we know), led an army at least once. Some fought personally, though only Cyrus died fighting. ${ }^{48}$ The personal combat between Artaxerxes II and the younger Cyrus came in a moment of existential threat and is only typical of such crises. Darius III (who before being king killed a Cadusian chieftain in single combat) took the field at Issus and Gaugamela but was careful to withdraw unscathed, provoking ancient accusations of cowardice and modern explanations that the king was too valuable to be allowed to die in battle. ${ }^{49}$ Artaxerxes II reportedly played an inspiring role in the retreat from a disastrous Cadusian campaign but not, apparently, in the preceding fighting. Darius III is (uniquely) ascribed a sort of pre-battle oration at Issus (Justin 11.9.8). ${ }^{50}$ Xerxes sought to inspire as gift-giving spectator (Herodotus 8.90).

${ }^{43}$ Xen., Cyr. 2.3.7-16, 8.3.2-8, 25-50.

${ }_{44}$ Briant 2002, 225-227.

${ }^{45}$ Hdt. 3.35, 36, 78, 5.105.

${ }^{46}$ Curt.10.1.30; Aristobul. 139 F51.

47 Plut., Artax. 3; cf. Strabo 15.3.18.

${ }^{48}$ Hdt. 1.214 (Cyrus); Xen., An. 1.8.26 etc. (Artaxerxes II); Arr. 2.10-11, 3.13-15 etc. (Darius III). Cyrus' death: Hdt. 1.214, Ctes. 688F9 (7-8). But Xen., Cyr. 8.7.1-28 has a different take on things.

${ }^{49}$ Rollinger/Ruffing 2012 argue that there is no imputation of panic (or therefore cowardice) in the Babylonian astronomical diary reference to Gaugamela. See also Rollinger 2016c.

${ }^{50}$ Xenophon makes his elder Cyrus denounce such speeches (Cyr. 3.3.49-55). His younger Cyrus has encouraging conversations with his entourage but only before the moment of battle is reached. 
In short, although the king could sometimes be pictured as inaccessible, Greek sources do not simply see him as a Chief Executive who never leaves company headquarters; but, all things considered, and with the possible exception of Cyrus, he is not primarily a warrior-king. ${ }^{51}$ Of course, one must acknowledge that even later Assyrian kings did not have themselves represented as engaging in actual fighting and Assurbanipal claimed that a dream-vision of Ishtar actually forbade him from participating in the war against the Elamite Teuman. ${ }^{52}$ Royal hands do not have to get dirty (or bloody) for there to be a positive valuation of war and what it can achieve. It is Teuman's head that hangs in a tree as Assurbanipal dines in his garden - another striking visual juxtaposition of the worlds of war and peace.

\section{Greek representations: the composition of Persian armies}

If kings and elite-members lead, what are the armies behind them like? Royal armies normally consist of contingents from many parts of the empire - the extreme example being the Herodotean Army List. But the Herodotean Army List is clearly a theoretical construct, not the description of a real army. If it is anything more than a paper entity, it must be seen in terms of military display. ${ }^{53}$ In any event, while we may acknowledge the ideological point in displaying the diversity of the king's power, we should concentrate attention on the core of the army.

We might seek to detect it (or some of its elements) in various special groupings, of which the most famous (though not the smallest or most elite) are probably the "Immortals," allegedly so-called because always kept at full strength, ${ }^{54}$ though some believe the name is a misunderstanding of a term meaning "followers." ${ }^{55}$ Isocrates' concept of an army "wandering with the king" assimilated military movements to the peripatetic existence of the king's court, ${ }^{56}$ and there are other overlaps between army and court. A chief court-personage, the chiliarch, bears a military title and is perhaps identical with the commander of the melophoroi - a group who give their name to a part of the palace (the Courtyard of the Melophoroi).$^{57}$ If Immortals were really "followers," that term could

51 In Plato's vision of the good kings of Achaemenid history, Cyrus is said to have spent his life soldiering, whereas Darius is not, even though his armies allegedly conquered more territory than Cyrus did: Leg. $694 \mathrm{a}, 695 \mathrm{e}$.

52 Cf. Macale 2014; Matthiae 2014, 391-392. Some of the unpleasant events celebrating Teuman's defeat were performed at Arbela in Ishtar's honour (Fuchs 2009, 99-104).

53 Darius III is represented as fearing that a multi-ethnic army would be rendered ineffective by linguistic diversity (Diod. 17.53.7) - a royal dispraisal of anything outside the core, and slightly ironic in view of the trope in the Babylonian version of royal inscriptions about the king's rule over people of all languages: DE, DNa, DSe, $\mathrm{XPa}, \mathrm{XPb}, \mathrm{XPc}, \mathrm{XPd}$, XPf, XPh, XV. The OP and Elamite versions speak merely of people of all or many types.

${ }^{54}$ For which Lincoln 2012, 99 claims the pomegranate spear-ends are a supportive argument.

55 For a brief summary see Schmitt 2004.

56 4.145. See Tuplin 2014b, 679. I wonder if the 24,000 troops immediately around Xerxes as he leaves Sardis (Hdt. 7.41) give one a sense of this group. Perhaps it is also "the army" that was vexed at Xerxes II's murder (Ctes. 688 F14[49]). Aristophanes understood that, when he leaves home, the king does so with an army (Ach. 81).

${ }^{57}$ Courtyard: Heraclid. 689F1. Chiliarchs: Aesch., Pers. 304; Plut., Them. 27, 29; Ael., VH 1.21; Nepos, Con. 3; Ctes. 15(49); Polyaen. 7.12, 17; Diod. 17.5, 3 F174; Meeus 2009; Keaveney 2010; Charles 2015a, 2015 b, 2016. 
also designate distinguished courtiers. Mutatis mutandis that goes for the title "Relative." (One should remember all those high officers who were actual relatives of the king and an Aramaic text from Elephantine that seems to envisage supreme power lying not just with the King but with "the King and the Sons-of-the-House," i.e. relatives. ${ }^{58}$ ) The fetishization of banal terms is also shown by Gobryas' designation as "Spearman," which corresponds to Aspathines' designation as "Clothes-bearer" (i.e. Chamberlain vel sim.), and by lower-level "spearmen" in the Fortification archive. ${ }^{59}$ Meanwhile Herodotus is aware that resourcing the King's Table involves supplying an army (1.192): this coheres with the remarks of Heraclides about the court (689 F2) and perhaps grosso modo with other texts in the Fortification archive. We may also, of course, be reminded of the numerous spearmen on the walls of Persepolis. (Some believe the 100 Column Hall was the dining space of the Royal Guard.)

If the core army is actually a Persian court army stationed in the heart of the empire, questions arise about the rest of the empire. I have argued elsewhere that the western provinces' military establishment was light in Iranian infantry (Tuplin 2016). This is a world in which Persians held a strategic spot like Syene-Elephantine with Semitic mercenaries \& small Iranian officer-class and in which a mass of Greeks appearing out of the snow at an Armenian underground village are readily accepted as troops on their way from the King to the local satrap (Xenophon, Anabasis 4.5.9). Satrapal troops do not need to be distinctively Iranian. (We actually know that many of them in Armenia were East Anatolian mercenaries. ${ }^{60}$ ) Persian control brought Iranian cavalry, but Iranian infantry might be little in evidence beyond the quasi-royal satrap's quasi-royal guards. When large and tactically diverse armies were needed in the west, they came from the centre, and Greek imputations of the relative slowness with which they were deployed suggest that, elite core notwithstanding, there was no standing army in any substantively meaningful sense of that term.

There is a paradox here. Greek sources assert that Persians underwent military training (like Spartans!) and had to serve in the army; and they assume that selectionfor-quality characterizes elite units of the core royal army. ${ }^{61}$ That might seem to presuppose a much larger body of trained soldiers who would be quickly available (like the elite) for service. But in practice this was apparently not so. Perhaps Persia's demographic resources were insufficient to support a large permanent military establishment even at home. Perhaps the Persian army as a whole was not as much bigger than the elite core as one might imagine and/or the economic basis on which most of the Persian population lived did not make it easy to export large amounts of it in military form without long preparation. Perhaps the King's desire to have a substantial force in attendance at all times militated against rational deployment of military resources. Perhaps Greek sources misrepresent the time it had to take to deploy from centre to periphery. In any event, so far as ideology goes, one may feel that the value-system

58 TADAE A4.7:2-3 // A4.8:2. But I hesitate to think this is a mere title, available to those who were not properly members of the royal family.

59 Gobryas and Aspathines: DNc, DNd. Fortification tablets: Tuplin (forthcoming [c]).

${ }^{60}$ Xen., An. 4.3.3, 4.18; cf. Cyr. 3.2.7, 25-27, 7.2.3f.

${ }^{61}$ Xen., Cyr. 1.1.10, 12; Strabo 15.3.18 (wide range of skills); Xen., An. 1.9.2 (riding, archery and spear-throwing); Hdt. 1.136; CEG 2.888 (riding and archery); Plat., Alc. 121e (riding); Hdt. 7.41; Heraclid. 689 F1. 
that informs the core army is more royal than martial: the primary force driving those aspiring to be selected into the core units is proximity to the king not a code of military excellence.

\section{Greek representations: religious dimensions}

In royal inscriptions the consequences of war are under the aegis of Ahuramazda; and violent action can be provoked by people worshipping the wrong gods. What about the world of Greek authors?

Religious revenge helps justify wars of conquest, and Xerxes' decision about Greece was manipulated by quasi-divine forces. ${ }^{62}$ Violence towards others people's religious environment is a feature of Persian military practice: but much of this is confined to the era between the burning of Cybele's sanctuary in 499 and late 479 BC. ${ }^{63}$ There are earlier examples (Darius in Chalcedon and Cambyses in Egypt, though the latter is not historiographically straightforward) but Artaxerxes III's looting of Egyptian religious material in 343 (specifically the removal of holy anagraphai together with gold and silver objects) is the only notable later example - and, even so, they were allegedly returned later for a ransom. ${ }^{64}$ Interestingly, outside Egypt, removal of cult-statues or the like is not a military topos. Athenian cult-statues were destroyed in 480 , not carried off ${ }^{65}-$ though Harmodius and Aristogeiton were. Xerxes' interest in Delphi was in its wealth (Herodotus 8.35-39); the same goes for a gold statue removed from the Babylonian temple of Bel-Marduk (1.183). In Near Eastern tradition an enemy's gods could be removed as a symbol of the conqueror's dominance and/or to protect them from the evil forces the conqueror had intervened to suppress. There seems little clear trace of this in Achaemenid contexts: Egypt in 526 and 343 would be the most likely exception, but neither is a straightforward case. Meanwhile Datis was protective attitude towards Delos in 490 and returned a statue that was wrongly removed from Delium. ${ }^{66}$

Persian commanders observed omens and made sacrifices (not necessarily to Persian deities) like most of their ancient counterparts. From a Greek perspective this would be unremarkable. Slightly more odd might be the (a) the presence of religious symbols such as the empty "chariot of Zeus" or sacred horses or standards showing the winged-disk figure $^{67}$ or (b) the nature of some rituals (whip, fetters and offerings at the Hellespont; human

${ }^{62}$ Ctes. 688 F13(21); Hdt. 5.102, 6.101; 7.12-18. See Harrison 2015.

${ }^{63}$ Chalcedon: Ctesias 688 F13(21). Anatolia, Greece 499-479: 6.19, 31-32, 96, 101, 8.32, 33, 53-56, 109, 143, 144, 9.13, 65; Aesch., Pers. 809f; Isoc. 4.155f; Plut., Per. 17; Cic., Leg. 2.10; Rep. 3.9,14; Strabo 634; Paus. 1.16.3, 8.46.3. Diod. 5.63 postulates a general Persian looting of sanctuaries except Hemithea.

${ }^{64}$ Chalcedon: Ctes. 688F13(21). Cambyses: Hdt. 3.29, 37; Diod. 1.46, 49, 95; Strabo 17.1.27, 46; Bernand/Bernand 1960, 29.8; Hecat. 264 F19a; Just. 1.9; Tuplin 2014, 148-149; Tuplin (forthcoming [d]). Artaxerxes III: Diod. 16.51.2; Plut., Is. Os.11; Ael., NA 10.28; VH 4.8,6.8. The Hellenistic trope about Ptolemaic restoration of statues taken by the Persians may be unreliable evidence about actual Achaemenid behaviour: Winnicki 1994; Devauchelle 1995, 71-72; El-Masry - Altenmüller-Thissen 2012.

65 Unless one trusts the tradition in Pausanias $(1.16 .3,8.46 .3)$ about statues from Brauron (and Didyma).

${ }^{66}$ Hdt. 6.97, 118.

${ }^{67}$ Chariot: Hdt. 8.115. Horses: Hdt. 1.189. Standard: Xen., An. 1.10.12; Nylander 1983; Raeck 1981, P586 $=$ Louvre G $117=\mathrm{ARV}^{2} 433.62$. 
sacrifice at the R. Strymon). ${ }^{68}$ But these are confined to specifically royal expeditions. Persian conduct of warfare in general did not have any very distinctive religious quality.

Nor did the outcome. Although the theology of Achaemenid kingship might entail that kings thanked their god publicly for victory, we cannot say they did so in ceremonies rich in military symbolism. Indeed we cannot document a specific public ritual of victory-celebration at all. Nepos represents the rebel Datames as erecting a trophy after defeating Autophradates (Datames 8), but, although Hesychius claims that nigla was the Persian word for trophy, ${ }^{69}$ this is not normal Persian practice in the narrative tradition. (Perhaps it was really done by Greek mercenaries.) Greek trophy-erection was structurally connected with the post-battle collection of the dead - something about which Persians were apparently not systematically concerned. Behistun shows them counting the enemy dead (see above), Herodotus represents Xerxes as concealing his own dead at Thermopylae (8.24), and elite Persian victims at Granicus, Issus or Gaugamela can be listed by name. But the fate of the generality of Persian dead is unremarked. Agesilaus' alleged return of Persian corpses under a truce after the battle of Sardis in 395 is unique. ${ }^{70}$ One may wonder what this says about Persian military values: were the Persian dead not worth saving from decay or enemy mistreatment?

\section{Greek representations: the character of Persian war-making}

The mutilations, impalements and sometimes huge battlefield casualty figures of the Behistun narrative stand in contrast to the "pacific" mode of other royal texts, and other iconographic material does not greatly change the situation: on seal-stones there is one certain prisoner-execution, and other images might have the same intent (rather than symbolizing the combat that precedes taking of prisoners) but for the most part there is no special brutality. ${ }^{71}$ In the Greek tradition Herodotus famously wrote that until Marathon Greeks were unable to endure the sight of Median clothing or the sound of the name "Mede." 72 There are some reports of large casualties among defeated enemies, ${ }^{73}$ and Mardonius' critique of Greek fighting implies it would be good to annihilate one's enemy as long as one did not suffer badly oneself. It is hard to say whether any of this amounts to conscious representation of Persians as peculiarly bloodthirsty fighters. Plato (Laws 697D) spoke of Persian despots who for small advantage completely overturn cities and nations, destroying them with fire; and destruction (not just looting) of cities and sanctuaries, often by fire, is a feature of a number of operations. ${ }^{74}$ We also hear of

${ }^{68}$ Hellespont: Dan 2015. Strymon: Parker 2004.

${ }_{69}$ Brust $(2008,480-482)$ links it to a putative *ni-gna = "victory."

${ }^{70}$ Hell. Oxy. 15 (Chambers). That this is not mentioned in Xen., Hell. 3.4.24 or Ages.1.32-34 may justify suspicions about its historical accuracy.

71 Execution: Porada 1979, 83, 86 fig. 45. Other items: Bregstein 1993, no. 189 = Balzer 2007, Kat. A3b.1; Boardman 2000, pl. 5.6. See Tuplin (forthcoming [a]).

72 6.112. See Tuplin 2013.

${ }^{73}$ Ctes. 688 F9(7), 13(10); Hdt. 3.147, 5.102, 119, 6.18, 9.113; Diod. 15.91; Polyaen. 7.11.6, 28.1. The Nabonidus Chronicle has Cyrus inflict great slaughter at Opis (Kuhrt 2007, 51 [3.1]).

${ }^{74}$ Ctes. 688 F13(21); Hdt. 4.123, 6.9, 25, 31, 33, 96, 101, 8.333, 50, 109, 140, 143, 9.13,65; Aesch., Pers. 65,104-5; Diod. 11.14-15. For Greek burning of enemy cities cf. Xen., Hell. 6.5.32 (Thebans in Laconia). 
castration, enslavement and deportation, ${ }^{75}$ as well as the killing or sacrificing of prominent prisoners (sometimes in large numbers), ${ }^{76}$ while indiscriminate slaughter is postulated on Samos in c.520, albeit in special circumstances (Herodotus 3.147). Routine decapitations or mutilations in the Assyrian manner are less apparent, although corpses are occasionally mistreated, invalids captured before Issus were mutilated or tortured and killed, and Alexander met mutilated Greeks near Persepolis. ${ }^{77}$ Nor should one forget the women gang-raped in Phocis is $480 \mathrm{BC}$, though the report is unparalleled. ${ }^{78}$ Oddly, if one sets aside the capture of Sidon in 345 (Diodorus 16.45), Plato's mid-fourth century generalization about later Achaemenid kings and Alexander-era items, almost everything salient comes from Herodotus. ${ }^{79}$ Ctesias' Persika reported some exquisitely revolting methods of execution-by-torture deployed against individual rebels and others who offended Achaemenid Kings or Queens. Such stories show Persians were capable of inventive cruelty (although some are tempted to think they say more about Greek invention), but also point up the absence of such Grand Guignol in Herodotus and the general disinclination of Greek sources (including Ctesias) to cast Persian armies as exponents of vicious battlefield warfare or to dwell in detail on examples of military frightfulness. ${ }^{80}$ Persian armies sometimes caused destruction and human displacement on a large scale, but their enemies do not seem to picture them in such a dark light as the Assyrians pictured themselves. ${ }^{81}$ Assyrians invested frightfulness with ideological significance, ${ }^{82}$ and doubtless the Persians did the same, but it remains unclear how often the situation arose. Meanwhile, Greeks were capable of shooting, butchering, crucifying, drowning, precipitating or hanging captives, ${ }^{83}$ and there were cases of aggravatedly unpleasant behaviour

${ }^{75}$ E.g. Hdt. 1.161, 4.203, 5.27, 6.9, 18-20, 25, 31, 94, 96, 101.

${ }^{76}$ Killing: e.g. Hdt. 3.14, 159, 8.127; Xen., An. 2.6.1; Diod.16.45; Ctes. 688F14(39), 15(50), 15(52), 15(53); Theop. 115 F291; Callisth. 124 F2. The context is characteristically punishment of rebellion. Sacrificing: Hdt. 1.86 (aborted), 7.114, 180.

${ }^{77}$ Corpses: Hdt. 6.30, 7.238 (but claiming such behaviour was unusual), 9.78; Xen., An. 1.10.1, 3.1.17; Ctes. 688 F16(64,66); Strabo 15.3.17. Issus: Arr. 2.7.1; Curt. 3.8.15. Persepolis: Diod. 17.69; Curt. 5.5.5-24; Just. 11.14.11-12. Rather less extreme is the branding/tattooing of Thebans in Hdt. 7.233.

${ }^{78}$ Pritchett 1991, 239 cites Burn 1987, 48-50 on vase-pictures of "Persians chasing women" as though pertinent to war-time rape. This refers to CA 3668 (M24), Private Coll. (M25) and Ruvo 1515 (ARV2 1550.4): but the topic is rare, Burn's discussion is inconclusive (the image might actually be of Pelasgians raping Athenians rather than a "Persian war scene"), and I doubt we can infer anything useful from this material.

${ }^{79}$ Irrespective of source, a great deal of it is also due to royal armies or appears in other major expeditionary contexts. Rollinger 2004 notes an alignment in Herodotus between unpleasant violence and despotic rule (not just Persian rule). On cruel punishments, see also Jacobs 2009.

${ }^{80}$ Xenophon (An. 3.1.17) conjectures that defeat or capture will lead to torture. But this hint of relatively extensive post-battle torture has to be read in the light of the arrest of the generals and their imagined fate (3.1.29), longing, but not able, to die. What Xenophon says is informed by fears about the fate of a small number of high rank persons, not (perhaps) by knowledge that Persians habitually mistreated quite large numbers of captives. I hesitate to infer such habitual behaviour from Isocrates' remark (4.152) that the Persians treated their own troops in Cyprus in the 380s (who suffered food-shortages: Diod.15.3) more outrageously than their prisoners-of-war.

${ }^{81}$ The viciousness of Assyrian narrative has an analogue in Homeric narrative: on that comparison, see Rollinger 2015, 21-24.

${ }^{82}$ Fuchs 2009; Liverani 2014.

${ }^{83}$ Pritchett 1991, 205-223. 
in such contexts. ${ }^{84}$ Greek representation of Persian military cruelty may tacitly reflect an awareness that they were not divided by that wide a gulf.

\section{Conclusions?}

Where does all of this leave us? Although Persians sometimes appear as quasi-Spartans, this idea is not strong in the tradition as a whole. Nor is the judgement that the first proof of manliness is quality as a warrior. Such quality is not regularly denied, though that does happen and acknowledgement of martial vigour can coexist with criticism for lack of skill, but there is no consistent sense of it as a defining feature of Persians, just as there is no firm intent to convey the idea of military kingship. In Xenophon's Oeconomicus war is structural, but only in the sense of there being a fiscal model for defence of provincial territory - a system heavily dependent on non-Iranians. This is a vision from deep into the post-conquest era; things might have seemed different 150 years earlier. But even then Greek observers do not discern a structural social need for fighting. Nor are there many signs of a distinctive military code of honour: people are servants of the king, not of an ideal of martial valour. Both in practical and ideological terms it is hard to characterize the interaction between the Persians as source of the most highly valued military units and the multi-ethnic empire's wider military capacity. Some believe the kardakes mentioned occasionally in late imperial period were recruited from various ethnic groups to be trained as Persian-style infantry. ${ }^{85}$ If so, they are the only sign of the empire's wider demographic resources being used to strengthen core military capacity (something Assyrians took for granted). ${ }^{86}$ The impression otherwise is the reverse ${ }^{87}$ Such exclusivity might coexist with a strong sense of military identity - "we Persians are defined as the King's soldiers; we cannot let outsiders in" - but other epiphenomena of such a situation are not regularly or strongly on view. Perhaps the horse-riding courtiers, who - Xenophon said (Cyropaedia 8.6.10) - went hunting and practised martial skills might count. But how much further did it go (what about Immortals?) and is it a significant militarising phenomenon anyway?

Royal texts and monuments (especially post-Behistun) take an extreme line in suppressing active warfare. The evidence of seal-stones and other items provides substantive reason for what we would believe anyway, namely that royal discourse offers a skewed picture. It allows us to play with ideas of centre and periphery, but - just because it is another ideological game - it cannot prove anything more than royal discourse about reality. If Greek sources offered a strong and consistent line, we might assign them decisive authority. But they do not really do so. Given the longevity of the empire, the possibility of change and the certainty that we are dealing with a diverse collection of observers, this

${ }^{84}$ Hdt. 4.202, 9.120; Duris 76 F67; Thuc. 4.47; Xen., Hell. 2.1.31-32; Phanias ap. Plut., Them.13.

85 Arr. 2.8.6; Nepos, Datam.8; Strabo 15.3.18; Photius, s.v.; Hesychius, s.v.; Eustathius ad Iliad 2.289 (citing Pausanias and Aelius Dionysius). Briant 2002, 1036-1037; Charles 2012; Tuplin 2014b, 686-688.

${ }^{86}$ Antonio Panaino suggests to me that general Persian unwillingness to follow the Assyrian model in this respect - even though, having a geographically much bigger empire, they theoretically had a greater need to do so - favoured the emergence of a different ideological representation of war. Some of the practical consequences are the subject of Tuplin $2014 \mathrm{~b}$ and 2016.

${ }^{87}$ Gates-Foster 2014 provides a useful discussion of Persian and non-Persian ethnicity in the imperial programme. 
is not very surprising. Greeks primarily saw what differentiated Persians from themselves as the product of a wealthy court environment: that militated against assigning them a strong military ethos, and sometimes actually ruled it out. Isocrates in c. 380 despised the "army that wanders with the king" and "Persian bravery"; the Arcadian Antiochus said in 368 that he had seen 10,000 cooks and servants but no men capable of fighting Greeks; Xenophon in c. 360 postulated a Persian military capacity undermined by luxurious self-indulgence; in the 350s Plato blamed harem education for Persian kings having to rely on mercenaries because their own subjects are too disaffected. ${ }^{88}$ But in the same decade Demosthenes (14.31) assumes the Persians might theoretically attack Greece and his confidence that Greece would survive is based on the analogy of 480-479 and a hope that Persian-employed Greek mercenaries would not fight against fellow Greeks, not on a critique of Persian military ethos. All of these judgments are context-driven, none is from an author who could envisage the end of the empire (Tuplin 2014c), and none really allows us to see into actual Persian minds. One cannot help feeling that there must have been a difference between the conquest era and the longer period that followed, but part of our problem is that it was the conquest era that invented a royal discourse directing attention away from the raw facts of military violence - something true right back to Cyrus. In truth, a global assessment of how war was embedded in the elite Persian psyche remains elusive. That is a sad conclusion. But it is always good to acknowledge what one does not know. If the purpose of the Great King was once to extend the frontiers of the empire, the purpose of the careful historian is sometimes to extend the frontiers of ignorance.

Perhaps, though, I can end on a somewhat more positive note. My title is "War and peace in Achaemenid imperial ideology." I hope I have persuaded the reader that both war and peace do figure in Achaemenid imperial ideology, and war perhaps more than is sometimes suggested: indeed, methodologically speaking, it is quite striking that the Persian and Greek data-sets, radically different in content and character, turn out not to be that far apart in their depiction of an ideological environment in which military values played a larger role than is sometimes acknowledged but were less fundamental than one might have expected. The Persians' two greatest achievements in the fourth century were the recovery of Egypt and the recovery of Greek Anatolia. The former was eventually achieved straightforwardly by war. But the latter, though prepared by war (including a brief invasion of Greece in 393), was sealed by the so-called King's Peace. There may be a symbolic truth there.

\section{BIBLIOGRAPHY}

Balzer, W. (2007), Achaimenidische Kunst aus Babylonien. Die Siegel der Keilschriftarchive. Ikonographie. Stil. Chronologie, Ph.D. Dissertation: Munich.

Beaulieu, P.-A. (2007), Nabonidus the Mad King: A Reconsideration of His Steles from Harran and Babylon, in: M. Heinz, M.H. Feldman (eds.), Representations of Political Power, Winona Lake: $137-168$.

\footnotetext{
${ }^{88}$ Isoc. 4.145; Xen., Hell. 7.1.38; Cyr. 8.8.19-26; Plato, Leg. 697e.
} 
Bernand, A., Bernand, E. (1960), Inscriptions grecques et latines du colosse de Memnon, Cairo.

Boardman, J. (2000), Persia and the West, London.

Borger, R. (1956), Die Inschriften Asarhaddons, Königs von Assyrien, Graz.

Bregstein, L. (1993), Seal Use in Fifth Century Nippur, Unpublished Ph.D Dissertation: University of Pennsylvania.

Briant, P. (2002), From Cyrus to Alexander, Winona Lake.

Brust, M. (2008), Die indischen und iranischen Lehnwörter im Griechischen, Innsbruck.

Burn, L. (1987), The Meidias Painter, Oxford.

Calmeyer, P. (1983), Zur Genese altiranischer Motive, VIII: Die 'Staatliche Landcharte des Perserreiches', II, AMI 16: 109-263.

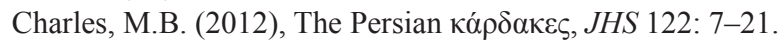

Charles, M.B. (2015a), Achaemenid Elite Cavalry: From Xerxes to Darius III, CQ 65: 14-34.

Charles, M.B. (2015b), The Chiliarchs of Achaemenid Persia: Towards a Revised Understanding of the Office, Phoenix 69: 279-303.

Charles, M.B. (2016), The Achaemenid Chiliarch par excellence, Historia 65: 392-412.

Charles, M.B., Anagnostou-Laoutides, E. (2016), Athenaeus, Clearchus and the Dress of the Persian Apple Bearers, IrAnt 51: 149-164.

Cook, R.M. (1982), Clazomenian Sarcophagi, Mainz.

Da Riva, R. (2008), The Neo-Babylonian Royal Inscriptions: An Introduction, Münster.

Dan, A. (2015), Grecs et Perses sur les detroits: le démon enchainé et la démesure du Grand Roi, $A W E$ 14: 191-235.

Devauchelle, D. (1995), Le sentiment anti-perse chez les anciens Égyptiens, Transeuphratène 9: 67-80.

El-Masry, Y., Altenmüller, H., Thissen, H.-J. (2012), Das Synodaldekret von Alexandria aus dem Jahre 243 v. Chr., Hamburg.

Fuchs, A. (2009), Waren die Assyrer grausam?, in: M. Zimmerman (ed.), Extreme Formen von Gewalt in Bild und Text des Altertums, Munich: 65-119.

Gates-Foster, J. (2014), Achaemenids, Royal Power and Persian Ethnicity, in: J. McInerney (ed.), A Companion to Ethnicity in the Ancient Mediterranean, Chichester: 175-191.

Gorman, V., Gorman, R.J. (2010), Truphē and hybris in the Peri Biōn of Clearchus, Philologus 154: 186-206.

Harrison, T. (2015), Herodotus on the Character of Persian Imperialism (7.5-11), in: A. Fitzpatrick-McKinley (ed.), Assessing Biblical and Classical Sources for the Reconstruction of Persian Influence, History and Culture, Wiesbaden: 9-48.

Henkelman, W.F.M. (2008), The Other Gods Who Are, Leiden.

Herrenschmidt, C. (1976), Désignations de l'Empire et concepts politiques de Darius Ir d'après ses inscriptions en vieux-perse, StudIran 5: 33-65.

Hyland, J. (2013), Vishtaspa krny: An Achaemenid Military Official in $4^{\text {th }}$-century Bactria, ARTA 2013.002.

Jacobs, B. (2009), Grausame Hinrichtungen - friedliche Bilder. Zum Verhältnis der politischen Realität zu den Darstellungsszenarien der achämenidischen Kunst, in: M. Zimmerman (ed.), Extreme Formen von Gewalt in Bild und Text des Altertums, Munich: 121-153.

Jacobs, B. (2014), Historische Aussagen in den Achämenideninschriften im Licht sich wandelnder Legitimationsstrategien, in: S. Gaspa, A. Greco, D. Morandi Bonacossi, S. Ponchia, R. Rollinger (eds.), From Source to History: Studies on Ancient Near Eastern Worlds and Beyond. Festschrift for Giovanni B. Lanfranchi, Münster: 341-352.

Keaveney, A. (2010), The Chiliarch and the Person of the King, in: B. Jacobs, R. Rollinger (eds.), Der Achämenidenhof, Wiesbaden: 499-508

Konijnendijk, R. (2016), Mardonius' Senseless Greeks, CQ 66: 1-12.

Kramer, N. (2004), Athen - Stadt des Grosskönigs!, Hermes 132: 257-270.

Kuhrt, A.T. (1988), Earth and Water, in: A.T. Kuhrt, H. Sancisi-Weerdenburg (eds.), Achaemenid History III: Method and Theory, Leiden: 87-100. 
Kuhrt, A.T. (2007), The Persian Empire: A Corpus of Sources from the Achaemenid Period, London. Lichtheim, M. (1976), Ancient Egyptian Literature: A Book of Readings II, Berkeley.

Lincoln, B. (2012), 'Happiness for Mankind'. Achaemenian Religion and the Imperial Project, Leuven. Liverani, M. (2014), The King and His Audience, in: S. Gaspa, A. Greco, D. Morandi Bonacossi, S. Ponchia, R. Rollinger (eds.), From Source to History: Studies on Ancient Near Eastern Worlds and Beyond. Festschrift for Giovanni B. Lanfranchi, Münster: 373-385.

Luckenbill, D.D. (1924), The Annals of Sennacherib, Chicago, Il.

Macale, L. (2014), Serse a Salamina, Scienze dell'Antichità 20: 15-27.

Matthiae, P. (2014), Image, Ideology and Politics: A Historical Consideration of the Message of Neo-Assyrian Reliefs, in: S. Gaspa, A. Greco, D. Morandi Bonacossi, S. Ponchia, R. Rollinger (eds.), From Source to History: Studies on Ancient Near Eastern Worlds and Beyond. Festschrift for Giovanni B. Lanfranchi, Münster: 387-404.

Meeus, A. (2009), Some Institutional Problems Concerning the Succession to Alexander the Great: prostasia and Chiliarchy, Historia 58: 287-310.

Nenci, G. (2001), La formula della richiesta della terra e dell'acqua nel lessico diplomatico achemenide, in: M.G.A. Bertinelli, L. Piccirilli (eds.), Linguaggio e terminologia diplomatica dall'antico oriente all'impero bizantino, Rome: 33-42.

Nylander, C. (1983), The Standard of the Great King: A Problem in the Alexander Mosaic, OpRom 19: $19-37$.

Orlin, L.L. (1976), Athens and Persia ca. 507 BC, in: L.L. Orlin (ed.), Michigan Oriental Studies in Honor of G.G. Cameron, Ann Arbor: 255-266.

Parker, R. (2004), Sacrificing Twice Seven Children: Queen Amestris' Exchange with the Gods under the Earth, in: V. Karageorghis, I. Taifacos (eds.), The World of Herodotus, Nicosia: 151-158.

Parpola, S. (1983), Letters from Assyrian Scholars II: Commentary and Appendices, Neukirchen-Vluyn.

Porada, E. (1979), Achaemenid Art Monumental and Miniature, in: R. Ettinghausen, E. Yarshater (eds.), Highlights of Persian Art, Boulder: 57-94.

Pritchett, W.K. (1991), Greek State at War V, Berkeley.

Raeck, W. (1981), Zum Barbarenbild in der Kunst Athens im 6. und 5. Jahrhundert v. Christ, Bonn.

Rollinger, R. (2004), Herodotus, Human Violence and the Ancient Near East, in: V. Karageorghis, I. Taifacos (eds.), The World of Herodotus, Nicosia: 121-150.

Rollinger, R. (2015), Old Battles, New Horizons: The Ancient Near Eastern Epics and Homer, in: R. Rollinger, E. van Dongen (eds.), Mesopotamia in the Ancient World, Münster: 5-34.

Rollinger, R. (2016a), Megasthenes, Mental Maps and Seleucid Royal Ideology: The Western Fringes of the World or How Ancient Near Eastern Empires Conceptualized World Dominion, in: J. Wiesehöfer, H. Brinkhaus, R. Bichler (eds.), Megasthenes und seine Zeit, Wiesbaden: 129-164.

Rollinger, R. (2016b), The Relief of Bisitun and Its Ancient Near Eastern Setting: Contextualizing the Visual Vocabulary of Darius' Triumph over Gaumata, in: C. Binder, H. Börm, A. Luther (eds.), Diwan: Studies in the History and Culture of the Ancient Near East and the Eastern Mediterranean. Festschrift für Josef Wiesehöfer zum 65. Geburtstag, Duisburg: 5-51.

Rollinger, R. (2016c), The Battle of Arbela in 331 BCE, Disloyal 'Orientals' and the Alleged 'Panic' in the Persian Army, in: S. Svärd, R. Rollinger (eds.), Cross-cultural Studies in Near Eastern History and Literature, Münster: 213-242.

Rollinger, R., Ruffing, K. (2012), 'Panik' im Heer - Dareios III., die Schlacht von Gaugamela und die Mondfinsternis vom 20. September 331 v. Chr., IrAnt 47: 101-115.

Root, M.C. (1979), King and Kingship in Achaemenid Art, Leiden.

Rung, E. (2015), The Language of Achaemenid Imperial Diplomacy towards the Greeks: The Meaning of Earth and Water, Klio 97: 503-515.

Sancisi-Weerdenburg, H. (1999), The Persian King and History, in: C. Shuttleworth-Kraus (ed.), The Limits of Historiography: Genre and Narrative in Ancient Historical Texts, Leiden: 91-112.

Schaudig, H.-P. (2001), Die Inschriften Nabonids von Babylon und Kyros'des Grossen, Münster.

Schmitt, R. (2004), Immortals, Encyclopaedia Iranica 13: 2-3.

Seux, M.J. (1967), Épithètes royales akkadiennes et sumériennes, Paris. 
Sevinç, N., Körpe, R., Tombul, M., Rose, C.B., Strahan, D., Kiesewetter, H., Wallrodt, J. (2001), A New Painted Greco-Persian Sarcophagus from Çan, Studia Troica 11: 383-420.

Summerer, L. (2007), Picturing Persian Victory: The Painted Battle Scene on the Munich Wood, ACSS 13: 3-30.

Summerer, L. (2009), Imaging a Tomb Chamber: The Iconographic Programme of the Tatarl $\mathrm{Wall}$ Paintings, in: S.M.R. Darbandi, A. Zournatzi (eds.), Ancient Greece and Ancient Iran: Cross-Cultural Encounters, Athens: 265-300.

Summerer, L. (2010), Wall Paintings, in: L. Summerer, A. von Kienlin (eds.), Tatarl. Renklerin Dönüsü, Istanbul: 120-185.

Tadmor, H. (1994), The Inscriptions of Tiglath-Pileser III, King of Assyria, Jerusalem.

Tadmor, H. (1999), World Dominion: The Expanding Horizon of the Assyrian Empire, in: L. Milano et al. (ed.), Landscapes, Territories, Frontiers and Horizons in the Ancient Near East, Padua: 55-62.

Tuplin, C.J. (2010), The Marathon Campaign: In Search of a Persian Dimension, in: K. Buraselis, K. Meidani (eds.), Marathon: Deme and Battle, Athens: 251-274.

Tuplin, C.J. (2013), Intolerable Clothes and a Terrifying Name: The Characteristics of an Achaemenid Invasion Force, in: C. Carey, M. Edwards (eds.), Marathon: 2500 Years. Proceedings of the Marathon Conference 2010, London: 223-239.

Tuplin, C.J. (2014a), The Changing Pattern of Achaemenid Imperial Coinage, in: P. Bernholz, R. Vaubel (eds.), Explaining Monetary and Financial Innovation, Cham-Heidelberg-New York-Dordrecht-London: $127-168$.

Tuplin, C.J. (2014b), From Arshama to Alexander. Reflections on Persian Responses to Attack, in: S. Gaspa, A. Greco, D. Morandi Bonacossi, S. Ponchia, R. Rollinger (eds.), From Source to History: Studies on Ancient Near Eastern Worlds and Beyond. Festschrift for Giovanni B. Lanfranchi, Münster: 668-696.

Tuplin, C.J. (2014c), The Sick Man of Asia?, in: G. Parmeggiani (ed.), Between Thucydides and Polybius. The Golden Age of Greek Historiography, Harvard: 211-238.

Tuplin, C.J. (2016), The Persian Military Establishment in Western Anatolia: A Context for Celaenae, in: A. Ivantchik, L. Summerer, A. von Kienlin (eds.), Kelainai-Apameia Kibotos: une métropole achéménide, hellénistique et romaine, Bordeaux: 15-27.

Tuplin, C.J., forthcoming (a), Sigillography and Soldiers: Cataloguing Military Activity on Achaemenid Period Seals, in: E. Dusinberre, M. Garrison (eds.), The Art of Empire in Achaemenid Persia. Festschrift in Honor of Margaret Cool Root, Leiden.

Tuplin, C.J., forthcoming (b), Plato, Xenophon and Persia, in: G. Danzig, N. Alon (eds.), Plato and Xenophon: Comparative Studies, Leiden.

Tuplin, C.J., forthcoming (c), Where Have All the Soldiers Gone? In Search of the Achaemenid Military Environment," in: M. Jursa (ed.), Governing Ancient Empires, Proceedings of the Final Conference of the NFN Imperium and Officium Project: Vienna, November 2014.

Tuplin, C.J., forthcoming (d), Dogs that do Not (Always) Bark. Herodotus on Persian Egypt, in: E. Irwin, T. Harrison (eds.), The Past in the Present: Interpreting Herodotus after Charles W. Fornara, Oxford.

Van der Spek, R. (1996), review of B. Oded, War, Peace and Empire: Justifications of War in Assyrian Royal Inscriptions, BiOr 53: 128-130.

Wiesehöfer, J. (2004), 'O Master, remember the Athenians.' Herodotus and Persian Foreign Policy,’ in: V. Karageorghis, I. Taifacos (eds.), The World of Herodotus, Nicosia: 209-222.

Winnicki, J. (1994), Carrying off and Bringing Home the Statues of the God. On an Aspect of the Religious Policy of the Ptolemies towards the Egyptians, Journal of Juristic Papyrology 24: 149-190. 